\title{
TEMA KAJIAN SKRIPSI MAHASISWA FAKULTAS TARBIYAH IAIN PALOPO (Deskripsi Kecenderungan Pilihan Tema-Tema Penelitian Pendidikan)
}

\author{
Oleh : Nursaeni \\ Fakultas Tarbiyah dan IImu Keguruan IAIN Palopo
}

\begin{abstract}
Abstrak:
Penelitian ini bertujuan menggambarkan tema-tema pembahasan skripsi mahasiswa Jurusan Tarbiyah IAIN Palopo, kecenderungan pilihan tema kajian skripsi mahasiswa Jurusan Tarbiyah berdasarkan ranking dan persentase dan kecenderungan pilihan tema kajian skripsi mahasiswa berdasarkan Program Studi menurut ranking dan persentase pada tahun 2013 dan tahun 2014. Jenis penelitian adalah analisis isi (content analysis). Data dikumpulkan dengan teknik dokumentasi. Sampel diambil secara acak dan proporsional dari beberapa progam studi (proportionate stratified random sampling) dengan jumlah 267 dari populasi yang sejumlah 893 dari empat Program Studi. Pengolahan dan analisis data dilakukan secara kualitatif dan kuantitatif. Secara kualitatif dimulai dengan kategorisasi jenis tema pada judul-judul skripsi mahasiswa. Analisis kuantitatif dilakukan dengan perhitungan persentase sederhana yang disajikan dengan tabel distribusi frekuensi untuk melihat kecenderungan tema skripsi mahasiswa. Hasil penelitian memperlihatkan bahwa tema-tema judul skripsi mahasiswa berada pada klasifikasi input, proses dan output pendidikan. Kecenderungan tema-tema judul skripsi baik pada tingkat Jurusan Tarbiyah secara keseluruhan, maupun pada tingkat Program Studi (Prodi), persentase dan ranking untuk masing-masing kategori yang sejenis menunjukkan kecenderungan pada tema-tema yang sama. Kategori input untuk seluruh judul skripsi mahsiswa jurusan Tabiyah didominasi oleh tema subyek siswa dan peserta didik dengan persentase mencapai mencapai $45,21 \%$ dari seluruh tema yang sejenis. Pada kategori proses didominasi oleh tema penerapan metode/teknik/strategi/ model/pendekatan pembelajaran dengan tingkat persentase sebesar 38,22 \%. sedangkan pada kategori output dominan pada tema prestasi/hasil belajar siswa dengan persentase sebesar $42,86 \%$.
\end{abstract}

\section{Kata kunci: Tema, Skripsi mahasiswa}

\section{A. PENDAHULUAN}

Pemilihan tema atau masalah penelitian pada skripsi mahasiswa selalu disesuaikan dengan spesifikasi bidang keilmuan mahasiswa pada jurusan atau prodi masing-masing. Pada mahasiswa jurusan Tarbiyah atau Fakultas Tarbiyah dan IImu Keguruan, ${ }^{1}$ tema yang disarankan harus sesuai dengan disiplin keilmuan Fakultas atau Jurusan Tarbiyah. yaitu masalah penelitian yang berkaitan dengan bidang pendidikan dan

\footnotetext{
${ }^{1}$ Penggunaan nama Fakultas baru digunakan pada tahun 2015 , sesuai tahun peralihan status STAIN ke IAIN.
} 
pengajaran. Bidang kajian dalam bidang penelitian pendidikan sangat kompleks. Tyler dalam Daly S. Naga dan Margono, mengingatkan bahwa faktor-faktor yang terlibat dalam penelitian pendidikan, kini makin bertambah kompleks. Kompleksitas masalah pendidikan diakibatkan oleh luasnya ruang lingkup pendidikan itu sendiri. ${ }^{2}$

IAIN Palopo, secara khusus Fakultas Tarbiyah pada saat masih berstatus Sekolah Tinggi Agama Islam (STAIN) setiap tahun telah menghasilkan ratusan karya skripsi sesuai jumlah alumni yang lulus pada tahun tersebut. Beragam judul skripsi yang diangkat oleh mahasiswa dengan bidang kajian masalah-masalah pendidikan. Hanya saja informasi dan deskripsi mengenai masalah-masalah penelitian. tersebut belum tertata secara baik sehingga tidak ada gambaran dan informasi secara jelas mengenai hal tesebut.

Informasi dan data mengenai persoalan-persoalan yang telah dikaji dalam penelitian mahasiswa menjadi penting, terutama sebagai bahan acuan dalam memilih tema-tema penelitian pendidikan yang tergolong belum banyak mendapat perhatian peneliti pendidikan, dan sekaligus memungkinkan terhindarnya peneliti dari praktik-praktik plagiasi ataupun terulangnya penelitian yang sama karena faktor ketidaktahuan peneliti. Karena itu hasil penelitian ini secara spesifik telah memberikan informasi dan peta yang menggambarkan pilihan tema-tema penelitian dalam skripsi mahasiswa, baik berupa kategorisasi, klasifikasi serta kecenderungan pilihan tema skripsi yang dipilih mahasiswa di Fakultas Tarbiyah IAIN Palopo. Berikut ini merupakan gambaran mengenai tema-tema penelitian dalam skripsi mahasiswa dari hasil penelitian penulis yang berjudul "Analisis Isi Tema -Tema Kajian Skripsi Mahasiswa Fakultas Tarbiyah IAIN Palopo Tahun 2013 -2014 (Deskripsi Kecenderungan Pilihan Tema-Tema Penelitian Pendidikan), dengan fokus masalah sebagai berikut:

1. Bagaimanakah gambaran tema-tema pembahasan judul skripsi mahasiswa pada tahun 2013 dan 2014

2. Bagaimanakah kecenderungan pilihan tema kajian skripsi mahasiswa jurusan Tarbiyah berdasarkan ranking dan persentase tahun 2013 dan 2014

3. Bagaimanakah kecenderungan pilihan tema kajian skripsi mahasiswa berdasarkan prodi menurut ranking dan persentase tahun 2013 dan 2014

\footnotetext{
${ }^{2}$ Margono, Metodologi Penelitian Pendidikan (Cet. I: Jakarta: Rineka Cipta, 1997), h. 14.
} 
Kajian mengenai analisis tema penelitian pendidikan pada perguruan tinggi, berdasarkan pengetahuan penulis masih tergolong langka, khususnya di IAIN Palopo. Salah satu penelitian yang relevan dengan tema penelitian penulis adalah penelitian yang dilakukan oleh I Made Tegeh mahasiswa Jurusan Teknologi Pendidikan Fakultas IImu Pendidikan Undiksa yang berjudul : "Arah Penelitian Pendidikan dan Budaya pada LPTK di Bali, penelitian dilakukan dengan metode survey. Beberapa temuan yang diperoleh yaitu:

1. Kuantitas penelitian pendidikan dan budaya tahun 2006-2008 di keempat LPTK di Bali meliputi penelitian Pendidikan 284 judul dan penelitian budaya 52 judul.

2. Tema penelitian didominasi oleh aplikasi strategi/model/pendekatan pembelajaran di kelas

3. Jenis penelitian didominasi oleh penelitian eksperimen, sedangkan penelitian budaya didominasi oleh penelitian kualitatif. ${ }^{3}$

Perbedaan penelitian penulis dengan penelitian I Made tersebut yakni, pertama bahwa peneliti lebih berkonsentrasi pada kajian kecenderungan tema-tema atau obyek penelitian pilihan mahasiswa pada bidang pendidikan dengan melakukan analisis isi pada judul-judul skripsi mahasiswa. Kedua, kajian atau penelitian yang dilakukan I Made tersebut sudah cukup lama, yaitu pada penelitian tahun 2006-2008. Sehingga kemungkinan waktu yang lama tersebut memungkinkan terjadinya perubahan arah atau kecenderungan tema penelitian. Sedangkan relevansi penelitian terdahulu tersebut dengan penelitian yang dilakukan penulis terdapat pada temuan kedua, yakni mencoba menggambarkan arah atau kecenderungan tema kajian penelitian.

\section{B. TEMA-TEMA PENELITIAN PENDIDIKAN}

\section{Pengertian Tema}

Pengertian tema sering disamakan dengan istilah topik. Dalam beberapa tulisan, disebutkan bahwa topik, tema dan judul pada dasarnya maknanya hampir sama, yaitu pokok pembicaraan baik dalam diskusi, dialog, pokok pikiran atau suatu karangan,

3IM Tegeh."Arah Penelitian Pendidikan dan Budaya pada LPTK di Bali" Pasca.undiksha.ac.id/ images/img_item/555.doc ( 6 Desember 2015) 
tulisan, atau nama yang digunakan dalam makalah atau buku. Istilah lainnya yang sering juga dimaknai sama dengan istilah tema, topik atau judul, yakni masalah penelitian, obyek penelitian demikian pula istilah fokus penelitian. Dalam Kamus Bahasa Indonesia tema berarti "pokok pikiran" dasar cerita, (yang dipercakapkan . . . .) ${ }^{4}$. Kerlinger mengatakan bahwa "sering kali tema adalah kalimat, suatu proposisi mengenai sesuatu. Tema-tema dikombinasikan menjadi himpunan tema." ${ }^{5}$ Dengan demikian pemahaman tema dalam pembahasan ini dimaknai sebagai pokok kajian atau topik bahasan.

\section{Klasifikasi Tema-Tema Penelitian Pendidikan}

Para pakar pendidikan mengemukakan bahwa masalah penelitian pendidikan termasuk masalah yang kompleks, karena masalah pendidikan adalah masalah yang luas. Tyler dalam Margono, menyebutkan delapan wajah yang merupakan peta konseptual pendidikan, yaitu

a) Mata pelajaran

b) Pelajar ( kegiatan dan itelegensia mereka)

c) Cara mengajar

d) Guru

e) Sekolah sebagai lembaga sosial

f) Lingkungan rumah

g) Lingkungan kawan sebaya (peer group)

h) Lingkungan masyarakat (community) 6

Selanjutnya Wina Sanjaya mengklasifikasikan tema penelitian pendidikan sebagai berikut: ${ }^{7}$
a) Sistem pendidikan
b) Input
c) Proses
d) Output

4Kamus Besar Bahasa Indonesia (KBBI), http:kbbi.web.id/tema (akses 10 November 2015)

${ }^{5}$ Kelinger. Foundation of behavioral research, Diterjemahkan oleh Landung R. Simatupang, dengan judul Asas-Asas Penelitian Behavioral ,(Yogyakarta: Tiara Wacana, 1998), h. 847.

${ }^{6}$ Margono, Metode Penelitian pendidikan (Cet.l; Jakarta: Rineka Cipta, 1997), h.15.

"Wina Sanjaya. "Tema atau Area Penelitian Pendidikan" Blog Muhammad Fais. Penelitian tindakan kelas dan model-model Pembelajaran. ( 30 Oktober 2015) 
e) Tripusat pendidikan

f) Bidang pendidikan

g) Mata pelajaran/bidang studi

Komponen sistem pendidikan sekaligus mencakup input-proses dan output,

a. Input meliputi, siswa/mahasiswa/peserta didik, guru, dosen atau pengajar, kurikulum yang dipakai, sarana/prasarana/ fasilitasb pendidikan, dan termasuk lingkungan belajar dan sebagainya.

b. Proses, pada proses mencakup hal perencanaan pendidikan, pelaksanaan, pengawasan. Bagaimana pembelajaran dilaksanakan, termasuk di dalamnya, macam strategi, model, media pembelajaran, dan sumber belajar, kompetensi guru dan tenaga pengajar, serta alat evaluasi proses pembelajaran di sekolah.

c. Output

Unsur output meliputi prestasi akademik, berupa nilai ulangan, nilai ujian Nasional, kejujuran, kesopanan, olahraga, kesenian, keterampilan kejujuran,

Gambaran tema penelitian pendidikan dalam sistem pendidikan sebagai berikut:

$$
\text { Input ------- Proses-------- Output. }
$$

Input merupakan bahan mentah yang meliputi, peserta didik, siswa atau mahasiswa, guru, pengajar atau dosen, dan lain-lain. Sedangkan proses mencakup praktik pendidikan, baik praktik kurikulum, bimbingan dan konseling. Pengklasifikasian tema sistem pendidikan ini menjadi fokus pengklasifikasian atau penggolongan tema-tema penelitian pendidikan dalam kajian ini.

\section{METODE PENELITIAN}

\section{Jenis Penelitian}

Penelitian ini merupakan Analisis Isi (countent analysis). Analisis dilakukan pada data yang didokumentasikan dari judul-judul skripsi mahasiswa yang bersi tema atau topik kajian bidang pendidikan. Penelitian ini akan mendeskripsikan dan memberikan inferensi atau kesimpulan mengenai kategori-kategori tema-tema atau topik-topik penelitian yang telah ditulis mahasiswa. Sebagaimana menurut Zuchdi dalam Andi Prastowo, bahwa analisis isi merupakan salah satu teknik penelitian untuk menghasilkan deskripsi yang 
obyektif, sistematis dan bersifat kuantitatif yang terungkap dalam komunikasi. ${ }^{8}$ Demikian pula menurut Arikunto yang menjelaskan bahwa metode penelitian analisis isi atau analisis dokumen adalah metode penelitian yang dilakukan terhadap informasi yang didokumentasikan dalam rekaman, baik gambar, suara, tulisan, atau bentuk rekaman lainnya. ${ }^{9}$ Judul-judul skripsi mahasiswa merupakan data yang tertulis dalam dokumendokumen, baik yang terdapat pada sumber primer, maupun sekunder. Analisis isi digunakan karena judul-judul skripsi mahasiswa merupakan data yang kompleks, dan jumlah banyak. Data yang demikian hanya bisa diteliti dengan teknik analisis isi.

\section{Sumber Data Penelitian}

Sumber data primer adalah sumber data mengenai tema penelitian mahasiswa yang berasal dari skripsi mahasiswa yang telah menyelesaikan tugas akhir pada tahun 2013 dan 2014. Sedangkan data sekunder adalah data yang diperoleh dari dokumendokumen yang memuat judul-judul skripsi mahasiswa yang terdapat di bagian arsip jurusan atau perpustakaan.

\section{Populasi dan Sampel Penelitian}

Populasi dalam penelitian ini adalah seluruh judul skripsi dari mahasiswa yang diwisuda pada tahun 2013 dan tahun 2014. Berdasarkan data yang diperoleh dari bagian administrasi Fakultas Tarbiyah jumlah judul skripsi mahasiswa selama dua tahun sebanyak 933 dari empat prodi, masing-masing prodi Pendidikan Agama Islam sejumlah 497 judul, Prodi Bahasa Inggris (Big) sejumlah 238 judul, Prodi Matematika sebanyak 167 judul, dan Prodi Bahasa Arab (Bar) sejumlah 31 judul.

Sampel yang digunakan adalah teknik proportionate stratified random sampling, yakni pengambilan sampel secara acak dan proporsional dari setiap strata. ${ }^{10}$ Pengambilan secara proporsional didasarkan pada prodi dan jumlah judul skripsi mahasiswa pada tahun 2013 dan 2014. Jumlah sampel berdasar strata prodi dan tahun digambarkan pada tabel 3.2. Besaran sampel diketahui dengan menggunakan rumus dari Isaac dan Michael

\footnotetext{
${ }^{8}$ Andi Prastowo, Memahami Metode-Metode penelitian (Cet.I;Yogyakarta: Ar-Ruzz Media, 2011),

${ }^{9}$ Suharsimi Arikunto, Manajemen Penelitian (Jakarta: Rieneka Cipta, 2003), h.321.

${ }^{10}$ Sugiyono, Metode Penelitian Administrasi, (Cet.XVIII:Bandung: Alfabet, 2010)., h.93.
} h.79. 
sebagaimana dalam Sugiono untuk tingkat kesalahan $5 \% \quad$ Rumus yang digunakan adalah sebagai berikut11:

$$
S=\frac{\lambda^{2} \cdot \text { N.P. Q }}{\mathrm{d}^{2}(\mathrm{~N}-1)+\lambda^{2} \cdot \mathrm{P} \cdot \mathrm{Q}}
$$

Tabel 3.2 Jumlah Sampel Berdasarkan Strata Tahun dan Prodi

\begin{tabular}{|c|c|c|c|c|c|}
\hline \multirow{2}{*}{ NO } & \multirow{2}{*}{ PRODI } & \multicolumn{4}{|c|}{ TAHUN } \\
\cline { 3 - 7 } & & Populasi & Sampel & Populasi & Sampel \\
\cline { 3 - 6 } & & 87 & 26 & 410 & 122 \\
\hline 1 & PAI & 84 & 25 & 154 & 46 \\
\hline 2 & BIG & 61 & 18 & 66 & 20 \\
\hline 3 & MAT & 8 & 3 & 23 & 7 \\
\hline 4 & BAR & 8 & $\mathbf{7 2}$ & $\mathbf{6 5 3}$ & $\mathbf{1 9 5}$ \\
\hline \multicolumn{2}{|c|}{ Total } & $\mathbf{2 4 0}$ & $\mathbf{7 2}$ &
\end{tabular}

\section{Teknik Pengumpulan Data}

Pengumpulan data dilakukan dengan menggunakan teknik dokumentasi untuk memperoleh tema-tema atau topik kajian skripsi yang terdapat dalam judul-judul skripsi mahasiswa. Data tema tersebut diinventarisasi lalu direduksi dengan membuat kategorisasi atau mengklasifikasi berdasarkan tema-tema pokok. Selanjutnya disajikan dalam suatu format atau tabel kategorisasi, dihitung dengan menggunakan tally (jajar lidi) untuk menghitung frekuensi dan prosentase. Serta penggunaan komputer program microsoft office excel 2007 dalam rangka mencari tema-tema penelitian dalam kategori yang sama Berdasarkan prosentase tersebut dibuat inferensi dan ranking kecenderungan tema-tema penelitian pendidikan pilihan skripsi mahasiswa IAIN Palopo tahun 2013 dan 2014, baik dilihat secara umum pada jurusan atau fakultasnya, maupun klasifikasi berdasarkan prodi.

\section{Instrumen Penelitian}

Data kualitatif penelitian ini diperoleh melalui instrumen utama yakni peneliti sendiri, dilengkapi dengan piranti komputer yang digunakan untuk mengecek jenis-jenis tema yang sama dalam satu kategori. Pada teknik kualitatif ini diawali dengan membuat kategorisasi. Kategorisasi dilakukan dengan menggunakan lembar analisis domain dengan

11/bid., h. 98. 
Model Spradley. ${ }^{12}$ Dengan menggunakan tabel yang berisi kategori rincian domain yang sejenis dikelompokkan (included term), lalu dimasukkan dalam jenis hubungan (semantic relationship). Untuk hubungan semantik, kategori difokuskan hanya dengan memilih kategori jenis saja. Selanjutnya dimasukkan dalam jenis kategori (cover term domain).. Selanjutnya data kuantitatif diperoleh dengan perhitungan frekuensi dan prosentese dengan menggunakan tally (jajar lidi).

\section{Teknik Analisis Data}

Analisis dilakukan dengan analisis data kualitatif maupun analisis data kuantitatif. Analisis data kualitatif dilakukan untuk mengklasifikasi dan mengkategorisasikan data kualitatif yang digambarkan dalam bentuk konsep atau katakata mengenai tema-tema atau topik bahasan yang dikaji dalam skripsi mahasiswa. Analisis kualitatif yang digunakan menggunakan model analisis domain dan analisis semantik, yaitu dilakukan untuk mengklasifikasikan tanda menurut maknanya, dan menggambarkan frekuensi seberapa sering obyek tersebut muncul. Dalam kaitan ini tema-tema yang sama dan dimasukkan pada kategori yang sama atau sejenis. Untuk mencari tema yang sama dilakukan dengan bantuan computer. Selanjutnya data kualitatif tersebut diolah dengan teknik analisis kuantitatif berupa tabulasi sederhana, yaitu dengan mencatat nilai-nilai bilangan atau frekuensi munculnya tema yang sama terhadap kategori atau jenis tema yang telah teridentifikasi, dengan memasukkannya dalam tabel distribusi frekuensi, selanjutnya menghitung persentase dengan rumus persentase ${ }^{13}$ : yaitu

$$
\mathrm{P}=\frac{I}{N} x 100 \%
$$

$\mathrm{f} \quad$ = frekuensi yang dicari persentasenya

$\mathrm{N}=$ Jumlah tema

$\mathrm{P} \quad=$ angka persentase

Selanjutnya data diurutkan berdasarkan urutan ranking sederhana dengan menggunakan komputer.

\footnotetext{
${ }^{12}$ James P.Spradley, Participant obsevation (United States of America, Holt Rinehart and Winston), h.94. 2012)h. 43.

${ }^{13}$ Anas Sudijono, Pengantar Statistik Pendidikan (Cet.XXIV; Jakarta: Rajagrafindo Persada,
} 


\section{HASIL PENELITIAN DAN PEMBAHASAN}

\section{Deskripsi Tema-Tema Pembahasan Skripsi Mahasiswa STAIN Palopo Tahun 2013-2014}

Klasifikasi kategori kecenderungan pilihan tema skripsi mahasiswa dilakukan dengan menggunakan kategori input, proses, dan output ${ }^{14}$. Sebagaimana disajikan dalam gambar berikut:

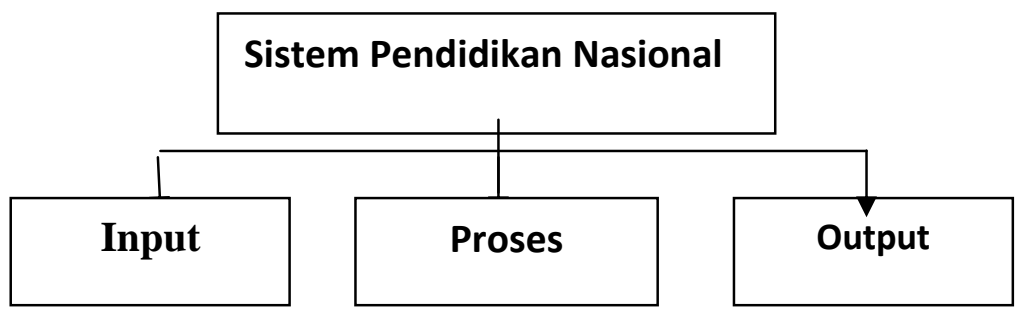

Gambar 4.1. Gambaran Sistem Pendidikan Nasional

Berdasarkan sistem pendidikan nasional tersebut, dan temuan berdasarkan hasil analisis data pada judul-judul skripsi mahasiswa, diperoleh komponen-komponen input yang berisi tema-tema kajian skripsi mahasiswa STAIN Palopo Tahun 2013-2014 dapat dibagi sebagai berikut:

a. Input

Kecenderungan tema judul skripsi mahasiswa pada kategori input meliputi:

1) Siswa/ Peserta Didik

2) Mahasiswa

3) Guru

4) Dosen

5) Kurikulum Yang Dipakai

6) Sarana \& Prasarana

7) Lingkungan Belajar

b. Proses

Kecenderungan Tema judul skripsi mahasiswa pada kategori proses meliputi:

1) Macam-macam Strategi Pembelajaran

2) Macam-macam Model Pembelajaran

${ }^{14}$ Wina Sanjaya. "Tema atau Area Penelitian Pendidikan" Blog Muhammad Fais.

Penelitian tindakan kelas dan model-model, akses 30 Oktober 2015 
3) Macam-macam Media Pembelajaran

4) Performa Guru/Siswa/Mahasiswa Dalam Kegiatan Pembelajaran

5) Penerapan Teori-teori Pembelajaran

6) Manajemen \& Pengelolaan Kelas

c. Output

Kecenderungan tema judul skripsi mahasiswa pada kategori output meliputi:

1) Prestasi Akademik

2) Prestasi Non Akademik

2. Deskripsi Kecenderungan Pilihan Tema Kajian Skripsi Mahasiswa Jurusan Tarbiyah Berdasarkan Ranking Dan Persentase Tahun 2013 dan 2014

Klasifikasi kategori kecenderungan pilihan tema skripsi mahasiswa dibatasi pada klasifikasi input, proses, dan output. Pada kategori input kecenderungan tema judul skripsi mahasiswa dominan pada tema kajian mengenai siswa, peserta didik atau mahasiswa pada berbagai aspek, mencapai $45,21 \%$, dari seluruh subyek kajian skripsi mahasiswa pada empat prodi di Jurusan Tarbiyah. Kecenderungan kedua adalah kajian mengenai anak, dengan persentase sebesar 19,13\%. Sedangkan kecenderungan ketiga mengarah pada guru dan sebagian dosen yang persentasenya mencapai 16,52\%. Menonjolnya kajian mengenai siswa, peserta didik atau mahasiswa, menandakan bahwa kajian skripsi mahasiswa mengarah pada aktifitas belajar di sekolah. Berikut gambaran kecenderung tema skripsi mahasiswa jurusan tarbiyah kategori input

Tabel 4.1. Kecenderungan Tema Skripsi Mahasiswa Jurusan Tarbiyah Kategori Input

\begin{tabular}{|l|l|c|c|}
\hline No & \multicolumn{1}{|c|}{ Kategori Tema } & Frekuensi (f) & Persentase (\%) \\
\hline 1. & Input & & \\
\hline & a. Siswa/peserta didik/ mahasiswa & 52 & 45,21 \\
\hline & b. Anak & 22 & 19,13 \\
\hline & c. Guru/dosen & 19 & 16,52 \\
\hline & d. Masyarakat & 12 & 10,44 \\
\hline & e. Kurikulum & 5 & 4,35 \\
\hline & f. Regulasi & 5 & 4,35 \\
\hline & Total & $\mathbf{1 1 5}$ & $\mathbf{1 0 0 , 0 0}$ \\
\hline
\end{tabular}

Pada kategori Proses, dominasi kecenderungan tema judul skripsi mahasiswa terdapat pada penggunaan metode, pendekatan, strategi, teknik dan model serta penerapan teori-teori dalam pembelajaran. (Istilah-istilah tersebut umumnya dianggap 
identik). Tema penerapan penggunaan metode mencapai prosentase 38,22\%. Dan jika digabung dengan seluruh istilah-istilah yg mirip di atas mencapai 58,67\%. Ini berarti bahwa fokus kajian tema skripsi mahasiswa di STAIN tahun 2013/2015 sangat terkait dengan aktifitas pembelajaran dalam kelas, sebagaimana pada tema di kategori input. Gambaran Kecenderungan Tema Skripsi Mahasiswa Jurusan Tarbiyah Kategori Proses pada tabel berikut:

Tabel 4.2. Kecenderungan Tema Skripsi Mahasiswa Kategori Proses

\begin{tabular}{|l|c|c|c|}
\hline NO & Kategori Tema & Frekuensi & Persentase (\%) \\
\hline $\mathbf{2 .}$ & Proses & & \\
\hline & a. Macam Penggunaan Metode & 86 & 38,22 \\
\hline & b. Pengelolaan program kelembagaan & 39 & 17,33 \\
\hline & c. Macam- macam media pembelajaran & 32 & 14,22 \\
\hline & d. Performance Guru & 17 & 7,56 \\
\hline & $\downarrow$ & 5 & 2,22 \\
\hline & j. Proses monitoring /evaluasi Proses & $\mathbf{2 2 5}$ & $\mathbf{1 0 0 , 0 0}$ \\
\hline
\end{tabular}

Pada kategori output, arah kecenderungan tema judul skripsi mahasiswa dominan pada tema "hasil" dan "prestasi belajar," yang mencapai 42,86\%. Sebagaimana halnya pada kategori input dan proses yang temanya mengarah pada aktifitas pembelajaran dalam kelas, maka demikian halnya pada kategori output. Kemiripan kecenderungan tema ini, oleh karena hasil dan prestasi belajar merupakan kelanjutan dari aktifitas input dan proses.

Kecenderungn Tema Skripsi Mahasiswa Jurusan Tarbiyah Kategori Output digambarkan pada tabel berikut: Tabel 4.3. Kecenderungan Tema Skripsi Mahasiswa Kategori Output/Outcome

\begin{tabular}{|l|l|l|l|}
\hline NO & Kategori Tema & Frekuensi & Persentase (\%) \\
\hline $\mathbf{3 .}$ & Output//Outcome & & \\
\hline & a. Hasil Belajar /Prestasi belajar & 57 & 42,86 \\
\hline & b. Kompetensi Apektif & 22 & 16,55 \\
\hline & c. Keterampilan berbicara & 21 & 15,80 \\
\hline & \multicolumn{1}{|c|}{} & & \\
\hline & h. Non akademik & 1 & 0,75 \\
\hline & i. Alumni /lulusan & 1 & 0,75 \\
\hline & TOTAL & $\mathbf{1 3 3}$ & $\mathbf{1 0 0 , 0 0}$ \\
\hline
\end{tabular}




\section{Deskripsi Kecenderungan Pilihan Tema Kajian Skripsi Mahasiswa Berdasarkan Prodi dan Ranking Tahun 2013 Dan 2014}

Klasifikasi kecenderungan pilihan tema skripsi mahasiswa berdasarkan Prodi lebih disederhanakan sebagaimana halnya pada tema Kajian Skripsi mahasiswa berdasarkan Jurusan, dibatasi pada kategori input, proses dan output saja. Sebagaimana halnya pada kecenderungan Tema Kajian Skripsi mahasiswa berdasarkan Jurusan, pada prodi Bahasa Arab dengan jumlah sampel 10 judul, hasil analisis kecenderungan tema judul skripsi mahasiswa tidak jauh berbeda. Pada kategori input didominasi oleh kajian mengenai siswa yang mencapai 56\%, pada kategori proses dominasinya pada penggunaan metode pengajaran yang mencapai 66,67\% dan pada kategori output kecenderungannya didominasi tema efektifitas metode yang mencapai 33,3\% dan keterampilan membaca sebesar $16,7 \%$ serta kemampuan berbicara bahasa Arab sebesar 16,7\%. Berikut kecenderungan tema skripsi mahasiswa Jurusan Tarbiyah Prodi Bahasa Arab kategori input, proses dan output digambarkan pada tabel berikut:

Tabel 4.7. Kecenderungan Tema Skripsi Mahasiswa Prodi Bahasa Arab Berdasarkan prosentase dan Ranking

\begin{tabular}{|c|c|c|c|}
\hline NO & Kategori Tema & Frekuensi (f) & Persentase (\%) \\
\hline \multirow[t]{7}{*}{1.} & Input & & \\
\hline & a. Siswa & 5 & $56 \%$ \\
\hline & a. Mahasiswa & 1 & $11 \%$ \\
\hline & b. Kesulitan-kesulitan belajar Bahasa Arab & 1 & $11 \%$ \\
\hline & c. Problema keterampilan membaca bahasa arab & 1 & $11 \%$ \\
\hline & d. Pentingnya Pengajaran IImu Saraf & 1 & $11 \%$ \\
\hline & Total & 9 & 100 \\
\hline \multirow[t]{8}{*}{2.} & Proses Pendidikan & & \\
\hline & a. Penggunaan metode pengajaran & 4 & 66,67 \\
\hline & b. Penerapan Metode Kelompok & 1 & \\
\hline & c. Penggunaan metode drill & 2 & \\
\hline & d. Penggunaan metode langsung & 1 & \\
\hline & e. Pengajaran ilmu saraf & 1 & 16,67 \\
\hline & f. Penggunaan media gambar & 1 & 16,67 \\
\hline & Total & 6 & 100,00 \\
\hline \multirow[t]{6}{*}{3.} & Output & & \\
\hline & Efektifitas metode & 4 & 33,3 \\
\hline & Peningkatan keterampilan membaca & 2 & 16,7 \\
\hline & Peningkatan kemampuan berbicara bahasa Arab & 2 & 16,7 \\
\hline & Pemahaman kosa kata bahasa Arab & 1 & 8,33 \\
\hline & Pemahaman bahasa arab & 1 & 8,33 \\
\hline
\end{tabular}




\begin{tabular}{|c|l|c|c|}
\hline & Keterampilan menulis & 1 & 8,33 \\
\hline & Penguasaan af'al & 1 & 8,33 \\
\hline & & 12 & 100,00 \\
\hline
\end{tabular}

Kecenderungan tema kajian skripsi mahasiswa Prodi Matematika masing-masing pada kategori input mengarah pada subyek siswa dengan persentase sebesar 76,92\%. Pada kategori proses sangat didominasi tema Penerapan Pendekatan/Model/Teknik/Metode/Strategi Pembelajaran dengan persentase sebesar 89,66\%, pada kategori output didominasi oleh tema Hasil belajar /Prestasi Belajar Matematika yang mencapai persentase $87,50 \%$.

Berikut kecenderungan tema skripsi mahasiswa Jurusan Tarbiyah Prodi Matematika kategori input, proses dan output digambarkan pada tabel berikut:

Tabel 4.8. Kecenderungan Tema Skripsi Mahasiswa Prodi Matematika Berdasarkan prosentase dan Ranking

\begin{tabular}{|c|c|c|c|}
\hline NO & Kategori Tema & Frekuensi (f) & Persentase (\%) \\
\hline \multirow[t]{7}{*}{1.} & Input & & \\
\hline & a. Siswa & 40 & 76,92 \\
\hline & b. Pokok Bahasan Relasi Dan Fungsi & 1 & 1,92 \\
\hline & c. Pola Asuh Orang Tua & 1 & 1,92 \\
\hline & $\downarrow$ & & \\
\hline & k. $\quad$ Persepsi & 2 & 3,85 \\
\hline & Total & 52 & 100,00 \\
\hline \multirow[t]{5}{*}{2.} & Proses & & \\
\hline & $\begin{array}{l}\text { a. Penerapan } \\
\text { Pendekatan/Model/Teknik/Metode/Strategi } \\
\text { Pembelajaran }\end{array}$ & 26 & 89,66 \\
\hline & b. Pemecahan Masalah Pada Materi Aljabar & 1 & 3,45 \\
\hline & c. Thinking Classroom & 1 & 3,45 \\
\hline & d. Bimbingan Belajar & 1 & 3,45 \\
\hline \multicolumn{2}{|r|}{ tal } & 29 & 100,00 \\
\hline \multirow[t]{8}{*}{3.} & Output & & \\
\hline & a. Hasil belajar /Prestasi Belajar Matematika & 35 & 87,50 \\
\hline & b. Hasil Project Work & 1 & 2,50 \\
\hline & c. Kompetensi Dasar Persamaan Kuadrat & 1 & 2,50 \\
\hline & d. Kecerdasan Emosional & 1 & 2,50 \\
\hline & e. Kecerdasan Intrapersonal & 1 & 2,50 \\
\hline & f. Kemampuan Komunikasi Matematika & 1 & \\
\hline & TOTAL & 40 & 100,00 \\
\hline
\end{tabular}

Kecenderungan tema kajian skripsi mahasiswa Prodi Bahasa Inggris pada kategori input mengarah pada subyek siswa dengan persentase sebesar 36,09 \% Pada kategori proses juga didominasi tema Penerapan Pendekatan/Model/Teknik/Metode/Strategi 
Pembelajaran dengan persentase sebesar 40,625 pada kategori output didominasi oleh tema Hasil belajar/Prestasi Belajar mencapai persentase 38,71. Berikut kecenderungan tema skripsi mahasiswa Jurusan Tarbiyah Prodi Bahasa Inggris kategori input, proses dan output digambarkan pada tabel berikut:

Tabel 4.9. Kecenderungan Tema Skripsi Mahasiswa Prodi Bahasa Inggris Berdasarkan prosentase dan Ranking

\begin{tabular}{|c|c|c|c|}
\hline NO & Kategori Tema & Frekuensi (f) & Persentase (\%) \\
\hline \multirow[t]{5}{*}{1.} & Input & & \\
\hline & a. Siswa & 48 & 36,09 \\
\hline & b. Mahasiswa & 18 & 13,53 \\
\hline & f. Analoglkata & 1 & 0,75 \\
\hline & TOTAL & 133 & 100,00 \\
\hline \multirow[t]{5}{*}{2.} & Proses & & \\
\hline & $\begin{array}{l}\text { a. penggunaan pendekatan/ model/ strategi/ } \\
\text { teknik/metode pembelajaran }\end{array}$ & 26 & 40,625 \\
\hline & b. penggunaan media & 12 & 18,75 \\
\hline & c. Kegiatan Interaktif Kelas & 1 & 1,5625 \\
\hline & Total & 64 & 100,00 \\
\hline \multirow[t]{8}{*}{3.} & Output & & \\
\hline & a. Kemampuan vocabulary (kosakata) & 24 & 38,71 \\
\hline & b. Keterampilan berbicara & 17 & 27,42 \\
\hline & c. Keterampilan Membaca & 10 & 16,13 \\
\hline & d. Keterampilan Menulis & 7 & 11,29 \\
\hline & e. Kemampuan Mendengarkan & 3 & 4,84 \\
\hline & $\begin{array}{llll}\text { f. } & \begin{array}{l}\text { Kompetensi } \\
\text { Keperawatan }\end{array} & \text { siswa } & \text { SMK } \\
\end{array}$ & 1 & 1,61 \\
\hline & Total & 62 & 100 \\
\hline
\end{tabular}

Kecenderungan tema kajian skripsi mahasiswa Prodi Pendidikan Agama Islam sangat beragam. Mengingat sampel yang cukup besar. Namun kecenderungan tema kajian skripsi mahasiswa tidak jauh berbeda dengan prodi sebelumnya. Kecenderungan tema pada kategori input dominan mengarah pada subyek siswa dengan persentase sebesar 16,01\%. Pada kategori proses juga didominasi tema Penerapan Pendekatan/Model/Teknik/Metode/Strategi Pembelajaran dengan persentase sebesar 33,68.\% pada kategori output dominan pada tema prestasi/hasil belajar mencapai $45,95 \%$. Berikut kecenderungan tema skripsi mahasiswa Jurusan Tarbiyah Prodi pendidikan Agama Islam kategori input, proses dan output digambarkan pada tabel berikut: 
Tabel 4.9. Rangkuman Kecenderungan Tema Skripsi Mahasiswa Prodi PAI Berdasarkan Persentase dan Ranking

\begin{tabular}{|c|c|c|c|}
\hline NO & & Frekuensi (f) & Persentase (\%) \\
\hline \multirow[t]{10}{*}{1.} & Input & & \\
\hline & a. Siswa/ Peserta Didik & 49 & 16,01 \\
\hline & b. Pendidikan Islam /PAI & 45 & 14,71 \\
\hline & c. Guru & 32 & 10,46 \\
\hline & d. Aqidah Akhlak & 29 & 9,48 \\
\hline & e. Anak & 17 & 5,56 \\
\hline & $\downarrow$ & & \\
\hline & V. Pendidikan Luar Sekolah & 2 & 0,65 \\
\hline & W. Dan 31 tema lainnya & 33 & 10,785 \\
\hline & Total & 306 & 100,00 \\
\hline \multirow[t]{14}{*}{2.} & Proses & & \\
\hline & a. Penerapan pendekatan/Model /strategi/ teknik /metode & 32 & 33,68 \\
\hline & b. Pelaksanaan Pembelajaran PAl & 10 & 10,53 \\
\hline & c. Pembinaan Sikap Siswa /remaja & 9 & 9,47 \\
\hline & d. Media & 4 & 4,21 \\
\hline & e. Penerapan Bimbingan dan Konseling & 4 & 4,21 \\
\hline & f. Kesiapan Mengajar Guru mendesain Pengajaran & 4 & 4,21 \\
\hline & $\downarrow$ & & \\
\hline & t. Meningkatkan Kecerdasan Kreatif & 1 & 1,05 \\
\hline & u. Mengatasi Kesulitan Membaca Al-Qur'an & 1 & 1,05 \\
\hline & v. Manajemen Pembelajarn Outdoor & 1 & 1,05 \\
\hline & w. manajemen Hubungan masyarakat & 1 & 1,05 \\
\hline & x. Ketaatan Siswa Pada Taat Tertib Sekolah & 1 & 1,05 \\
\hline & TOTAL & 95 & 100,00 \\
\hline \multirow[t]{11}{*}{3.} & Output & & \\
\hline & a. Prestasi Belajar PAl/Hasil Belajar & 34 & 45,95 \\
\hline & b. Kreatifitas & 7 & 9,46 \\
\hline & c. Kompetensi Guru & 4 & 5,41 \\
\hline & d. Mutu pendidikan & 4 & 5,41 \\
\hline & $\downarrow$ & & \\
\hline & q. Pengembangan Bakat Peserta didik & 1 & 1,35 \\
\hline & r. Pengembangan Perilaku Anak & 1 & 1,35 \\
\hline & S. Perkembangan PAI masyarakat & 1 & 1,35 \\
\hline & t. $\quad$ Alumni STAIN & 1 & 1,35 \\
\hline & TOTAL & 74 & 100,00 \\
\hline
\end{tabular}




\section{E. PENUTUP}

Gambaran tema-tema pembahasan pada judul skripsi mahasiswa pada tahun 2013 dan 2014 pada kategori input meliputi: Siswa/ Peserta Didik, Mahasiswa, Guru, Dosen, Kurikulum yang Dipakai, Sarana \& Prasarana, Lingkungan Belajar dan sebagainya. Kategori proses mencakup macam-macam strategi pembelajaran, macam-macam model pembelajaran, macam-macam media pembelajaran, Performa guru/siswa/mahasiswa dalam kegiatan pembelajaran, Penerapan teori-teori pembelajaran dan manajemen \& pengelolaan kelas, dan sebagainya. Sedangkan pada kategori output mencakup Prestasi Akademik dan Prestasi Non Akademik. Selain kategori tersebut, tema-tema penelitian mahasiswa juga dapat dilihat pada kategori Tripusat Pendidikan, Bidang Pendidikan Dan Mata Pelajaran.

Gambaran tema-tema skripsi mahasiswa secara keseluruhan pada Jurusan Tarbiyah berdasarkan ranking dan persentase tahun 2013 dan 2014 menunjukkan bahwa pada kategori input didominasi oleh pembahasan mengenai siswa/peserta didik sebagai urutan tertinggi dengan persentase sebesar 45,21 \%, Kecenderungan kedua adalah kajian mengenai anak, dengan persentase sebesar 19,13\%. Sedangkan kecenderungan ketiga mengarah pada guru dan sebagian dosen yang persentasenya mencapai $16,52 \%$. Selanjutnya pada kategori proses, tema penerapan penggunaan metode/teknik/strategi/pendekatan dan beberapa istilah yang identik keseluruhannya mencapai 58,67\%. Sedang pada kategori output, tema kajian skripsi mahasiswa yang dominan dan yang berada pada ranking tertinggi dengan tema hasil belajar dan prestasi belajar yang mencapai $42,86 \%$.

Kecenderungan pilihan tema kajian skripsi mahasiswa pada setiap prodi yang ada di Jurusan Tarbiyah menurut ranking dan persentase tahun 2013 dan 2014, tidak berbeda dengan kecenderungan pilihan tema skripsi mahasiswa secara keseluruhan di Jurusan Tarbiyah. Keempat Prodi, yaitu Prodi Bahasa Arab, PAI, Matematika dan Bahasa Inggris, memiliki kecenderungan pilihan tema yang sama. Yang berbeda adalah variasi pilihan tema terdapat pada prodi PAI yang beragam. Sebaliknya kecenderungan tema penelitian pada Prodi Bahasa Inggris cenderung lebih berkonsentrasi pada tema terbanyak. 


\section{DAFTAR PUSTAKA}

Arikunto, Suharsimi, 2002, Prosedur Penelitian Suatu Pendekatan Praktek, Cet. XII; Jakarta: Rineka Cipta,.

Ary, Donald.., at.all., Pengantar Penelitian dalam Pendidikan. Diterjemahkan oleh Arief Furchan. Surabaya: Usaha Nasional Indonesia, judul Asli: Introduction to Research in Education.tt..

Faisal, Sanapiah, 2003. Format-Format Penelitian Sosial, Cet. Vl; Jakarta: PT Raja Grafindo Persada,

Kerlinger, Fred N. 1998.Asas-Asas Penelitian Behavioral, Diterjemahkan oleh

Landung R. Simatupang, Yogyakarta: Tiara Wacana, Judul Asli: Foundation of Behavioral Research.

Margono, Metode Penelitian Pendidikan. Cet.l; Jakarta: Rineka Cipta..

Nawawi, Hadari dan Martini, Mimi. 1994.Penelitian Terapan, Cet.l; Yogyakarta: Gadjah Mada University Press,

Nazir, Mohammad, 1998. Metode Penelitian, Jakarta: Ghalia Indonesia

Prastowo, Andi. 2011.Memahami Metode-Metode Penelitian, Suatu Tinjauan Teoritis dan Praktis, Cet.l; Yogyakarta: Ar-Ruzz Media,

Sanjaya, Wina. "Tema atau Area Penelitian Pendidikan" Blog Muhammad Fais. Penelitian Tindakan Kelas Dan Model-Model Pembelajaran. Akses 30 Oktober 2015

Sarwono, Jonathan, 2011. Mixed Methods, Cara Menggabung Riset Kuantitatif dan Riset Kualitatif Secara Benar. Cet.l; Jakarta: PT. Elex Media Komutindo.

Setyosari, Punaji, 2012. Metode Penelitian Pendidikan dan Pengembangan.Cet.l; Jakarta: kencana.

Spradley, James P. Participant Obsevation. United States of America, Holt Rinehart and Winston.

Sudijono, Anas, 2012.Pengantar Statistik Pendidikan. Cet. XXIV; Rajawali Press.

Sugiono. 2002. Statistika Untuk Penelitian. Yogyakarta : Alfabeta,

Sukmadinata, Nana Syaodih. 2012. Metode Penelitian Pendidikan,Cet.VIII; Bandung: Rosdakarya.

Suyanto, Bagong.2011..Metode Penelitian Sosial.Cet.l; Jakarta: Kencana 